\title{
Considerations for pre-clinical models and clinical trials of pluripotent stem cell-derived cardiomyocytes
}

\author{
Jean-Sébastien Hulot ${ }^{1,2^{*}}$, Francesca Stillitano ${ }^{1}$, Joe Elie Salem ${ }^{2}$, Jason C Kovacic ${ }^{1}$, Valentin Fuster ${ }^{1}$ \\ and Roger J Hajjar ${ }^{1}$
}

\begin{abstract}
Pluripotent stem cells (PSCs) represent an appealing source from which to develop cell replacement therapies. Different initiatives have been launched to promote their development toward clinical applications. This article will review the main questions that should be considered before translating PSC-derived cardiomyocytes into clinical investigations, including the development of good manufacturing practice-level PSC lines, the development of efficient protocols to generate pure populations of cardiac myocytes, and the development of techniques to improve the retention and survival rate of transplanted cells.
\end{abstract}

Different disorders, notably through myocardial ischemia, can cause the critical loss of cardiomyocytes. This loss initiates a cascade of detrimental events, including the development of cardiac fibrosis, formation of non-contractile scar tissue and promotion of adverse ventricular remodeling - all mechanisms that can lead to heart failure and eventually death. Replacement of dead or dysfunctional cardiac myocytes through cell-based therapies has thus become an emerging and exciting strategy for the treatment of heart failure.

The restoration of damaged heart muscle tissue can be achieved through different strategies, including cell transplantation approaches [1]. Even if recent evidence suggests the existence of cardiomyocyte renewal in the post-natal mammalian heart $[2,3]$, the heart is one of the least regenerative organs in the body. Hence, a large number of cardiac myocytes are needed for replacement therapy.

\footnotetext{
* Correspondence: jean.hulot@mssm.edu

${ }^{1}$ Cardiovascular Research Center, Icahn School of Medicine at Mount Sinai, One Gustave L Levy Place Box 1030, New York, NY 10029, USA

UPMC Univ Paris 06, UMR_S ICAN Cardiometabolism and nutrition, Paris, France
}

However, human donor hearts and cardiomyocytes are in extremely limited supply, motivating a demand for alternative cardiomyocyte sources. The remarkable proliferative and differentiation capacity of stem cells represents an appealing strategy to provide an unlimited supply of specific cell types, including viable functioning cardiac cells.

Different types of autologous cells (including skeletal myoblasts, hematopoietic stem cells and mesenchymal stem cells) have been tested so far in pre-clinical and clinical trials but with inconsistent results [4-6]. In this review, we specifically focus on the use of pluripotent stem cells (PSCs) as a source for cell transplantation. PSCs have the ability to differentiate into cell types of all three germ layers, including cardiac and vascular cells [7-9]. Human embryonic stem cells (ESCs) were first isolated in 1998 and are derived from the inner cell mass of blastocyst stage embryos. They have the unique ability to self-renew indefinitely while maintaining the potential to differentiate into all cell types in the human body [10]. The use of human ESCs is, however, limited by different issues, including ethical concerns. The revolutionary discovery of induced pluripotent stem cells (iPSCs), whereby somatic cells (such as dermal fibroblasts or white blood cells) can be reprogrammed into an embryonic-like pluripotent state by the forced expression of a defined set of transcription factors [11], has provided another source of pluripotent stem cells [12]. Like ESCs, iPSCs are multipotent and clonogenic but can also offer autologous personalized therapy. The seminal understanding of pluripotency holds great promise for regenerative medicine and the use of ESCs or iPSCs as a source for cardiac repair has thus become an emerging and exciting field.

However, studies involving the transplantation of PSCderived cardiomyocytes into the heart have begun only recently. There are currently a very limited number of clinical studies using ESCs or iPSCs that have been approved [13]. In 2009, the Food and Drug Administration 
approved the first clinical trial using ESCs in patients with spinal cord injury, but the trial was discontinued due to funding challenges. PSCs are currently being tested to treat patients with two different forms of macular generation (Stargardt's macular dystrophy and age-related macular degeneration) using PSC-derived retinal pigment epithelial cells [14]. A pilot clinical study using iPSC-derived retinal pigment epithelium cells in patients with exudative age-related macular degeneration has been launched in Japan during summer 2013. It is noteworthy that no clinical trials using PSC-derived cardiomyocytes for the treatment of heart failure have been approved so far, but different research programs have been launched with the objective of treating patients within the next 5 years. This article reviews the main questions that should be considered before translating PSC-derived cardiomyocytes into clinical investigations (Figure 1).

\section{Generating good manufacturing practice and clinical-grade pluripotent stem cell lines}

Good manufacturing practice (GMP) criteria have been established by both the European Medicines Agency and the Food and Drug Administration to ensure optimally defined quality and safety in cell transplantation studies. The directive and guidelines are progressively evolving but include requirements for cell therapy products, including PSCs [15]. GMP is a requirement for good clinical practice and requires the development of standardized operating procedures and quality control methodology for the entire process from cell generation to storage of the cell therapy products [16]. For example, appropriate safety testing will be required for all animal-derived products. The use of feeder-free derivation protocols and the development of specific culture conditions that avoid xeno-components but rather use GMP-quality human derivatives would be preferable. Similarly, the generation of clinical-grade iPSCs with the use of virus-free non-integrative reprogramming techniques is probably desirable in the future. It is beyond the scope of this review to detail all the requirements to achieve a GMP-level cell product, but it is worth mentioning that the generation of clinical-grade PSCs is a critical first step toward future applications [16]. Even though the use of human ESCs and the derivation of iPSCs have become very popular during the past years and have been implemented in many research laboratories, the development of GMP-grade PSCs will require significant effort and resources that might be supported by a much smaller number of laboratories.

\section{Defining the ideal level of differentiation}

Different studies have clearly established that ESCs and iPSCs can differentiate into myocytes with some structural and functional properties of cardiomyocytes $[9,17]$. The differentiation is, however, heterogeneous, raising concerns about the persistence of undifferentiated

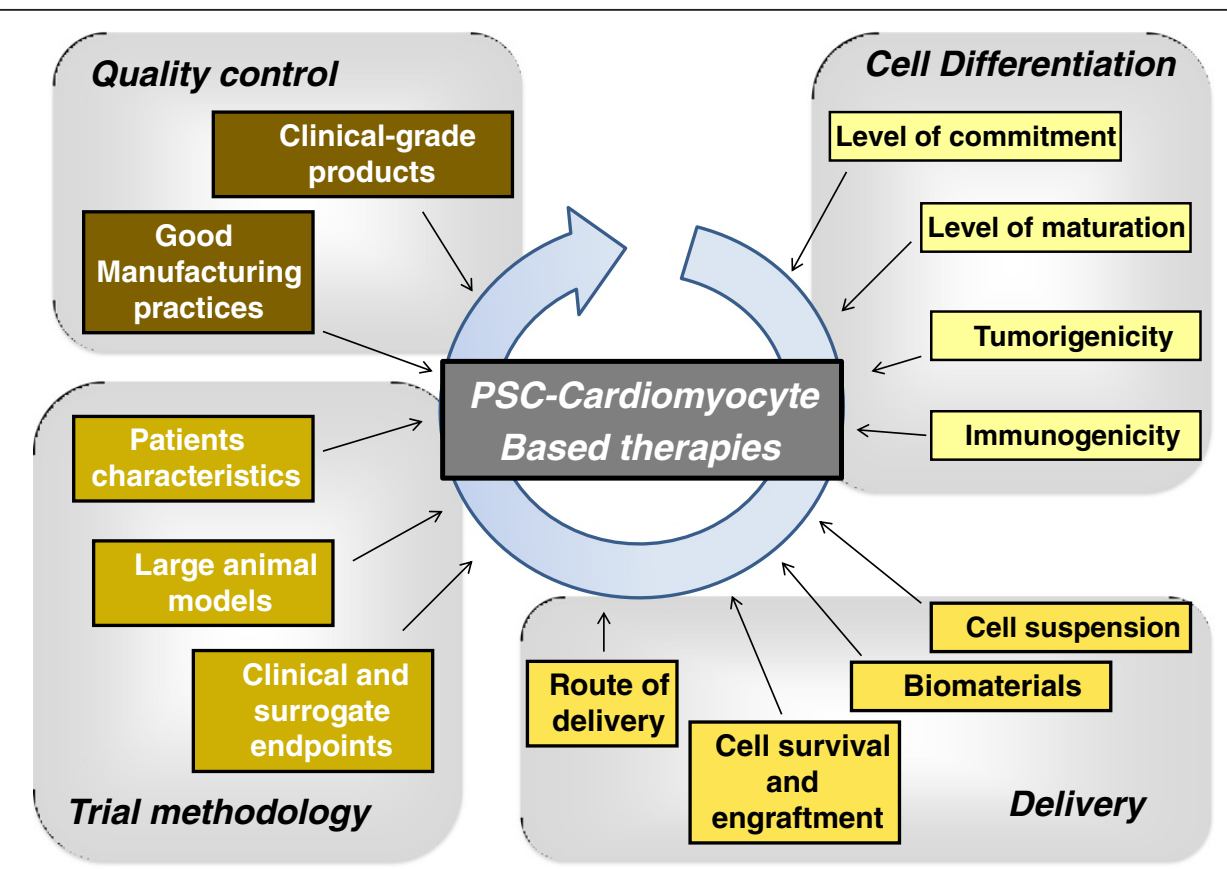

Figure 1 Overview of the key issues to be addressed before therapies based on pluripotent stem cell (PSC)-derived cardiomyocytes can be translated into clinical investigations. 
pluripotent cells in the cell mixture. The ability of undifferentiated ESCs to form teratomas, an encapsulated tumor that contains tissue components resembling normal derivatives of all three germ layers, when transplanted into normal or diseased hearts has been reported by different groups $[18,19]$. These concerns might even be stronger for iPSCs, as reprogramming and in vitro culture of these cells can induce genetic and epigenetic abnormalities $[20,21]$. As a consequence, ESCs or iPSCs will require some degree of pre-differentiation to restrict their differentiation repertoire and prevent tumor growth. Significant efforts are thus being made to optimize culture conditions for the generation of cardiac-committed cells from PSCs. Applying knowledge in developmental biology has guided the development of most of these protocols. In vitro cardiomyocyte differentiation mimics the process of cardiogenesis in vivo. The generation of human PSC-derived cardiomyocytes has primarily been performed through embryoid body formation [22,23] but is highly increased when human PSCs are exposed to activin A and bone morphogenic protein 4 [24]. Different types of cardiomyocytes, including atrial-, ventricular-, and nodal-like cells, are formed, however, which might not be optimal for cell transplantation purposes where highly homogenous populations of each cardiac subtype is desirable. The inhibition of the Wnt signaling pathway in later stages of the differentiation process has recently been associated with a marked increase in the production of ventricular-like cardiomyocytes $[25,26]$.

Different cell sorting strategies based on surface markers, differences in glucose and lactate metabolism or labeling with some fluorescent dyes have also been proposed to generate highly purified populations of PSCderived cardiomylocytes (up to $99 \%$ purity) [27-29]. Some studies have suggested that even a low number of undifferentiated cells might be sufficient to induce teratoma formation [30]. Using these methods, the potential contamination with undifferentiated cells should be kept under the level of concern. Accordingly, several studies found no teratomas in hearts transplanted with cardiomyocytes or cardiac progenitors derived from purified ESCs [17,31], suggesting the risk of tumor formation might be quite low after appropriate cell preparation. However, further analysis of the therapeutic potential of PSCs and their progeny, including the risk of teratomaforming propensity in animal models with long-term follow-up, is required before cell therapy with human PSCs can advance to clinical trials.

Using the current techniques of differentiation, PSCderived cardiomyocytes appear to be less mature than adult cardiomyocytes. Maturation of PSC-derived cardiomyocytes is, however, improved in the long term ( $>80$ days of in vitro differentiation and culture) [32] or by inducing adult-like metabolism with specific medium
[33]. However, whether more mature cells are preferable for cell transplantation experiments remains unclear. There is an intuitively attractive idea that the adult mammalian heart provides a 'cardiogenic environment' that will drive maturation and orientation of cardiac myocytes from pluripotent stem cells. Transplanted immature cells would have the opportunity to further mature in vivo [34]. In addition, the use of less differentiated but mesodermcommitted PSC-derived cells might not only restore myocardial tissue but could also contribute to revascularization. Further investigations are now needed to determine the ideal level of differentiation for cell transplantation using PSC-derived cardiomyocytes.

\section{Avoiding the rejection of transplanted cells}

As transplanted PSC-derived cardiomyocytes might not be of patient origin, the possibility of an immune response must be addressed [35]. Transplant rejection is mainly driven by allelic differences in the surface antigens expressed by the donor and recipient. There are three distinct types of transplantation antigens: $\mathrm{ABO}$ blood group antigens, minor histocompatibility antigens and major histocompatibility complex (MHC) molecules. Allelic differences in MHC molecules are, by far, the most significant immunological barrier to organ transplantation. Undifferentiated human ESCs are sometimes called 'immunoprivileged' because they express low levels of class I MHC (MHC-I) molecules [36-38]. However, MHC-I expression increases approximately 10 -fold with the induction of differentiation [38]. Stem cell graft rejection may be triggered when the recipients' allogeneic $\mathrm{T}$ cells recognize the foreign MHC-I surface molecules, whether differentiation occurs before or after transplantation. A number of methods have been proposed to address immunorejection [39]. Among them, derivation of ESCs that have their MHC (also called human leukocyte antigen (HLA) in humans) matched with the patient's could be a potential method for minimizing immunorejection in ESC transplantation $[40,41]$. In contrast with ESCs, the development of iPSC-derived differentiated cells has been expected to provide personalized sources for cell-based therapy. However, the overall time to generate, expand and characterize patient-specific iPSCs creates an important barrier to the development of such personalized approaches. Moreover, iPSCs were originally believed to be non-immunogenic but recent data have raised concerns about the potential immunogenicity of these cells. A recent study reported that the transplantation of immature iPSCs induced a T-cell-dependent immune response even in a syngeneic mouse, likely due to abnormal gene expression [42]. This immunogenicity could be linked to the over-expression of minor antigens potentially resulting from point mutations in the coding sequences of iPSCs [20] or the epigenetic 
regulation of iPSCs [43]. This observation was, however, not confirmed in two subsequent studies $[44,45]$.

One strategy to address this issue and avoid the use of intensive immunosuppressive agents is to create a collection of PSCs with distinct MHCs that will match the majority of the general population. It has, for instance, been reported that the generation of 50 iPSC lines would be sufficient to cover $90 \%$ of the Japanese population [46]. The panels of HLA types would, however, be higher in populations with high genetic diversity, thus requiring the generation of a higher number of iPSC lines. These HLAorganized banks of PSCs would certainly help to limit the risk of rejection but might not eradicate the immunogenic risk because of the limited number of HLA-compatible loci and the level of HLA typing resolution [47].

\section{Ensuring the survival and the engraftment of transplanted cells}

The survival and integration of transplanted cells into the host is a critical challenge. The first evidence that ESC-based therapies can engraft and form myocardium in vivo came from small animal models where human ESC-based therapies were directly injected into the normal myocardium [48]. Further experiments were then performed in diseased conditions, especially in ischemic hearts. While in animal models the number of cells and injections may vary, the common concept is to deliver cells in or around the infarcted myocardium. Most of these studies have shown that the grafted PSC-derived cardiomyocytes are mainly found as confluent cell clusters in the infarct border zone $[17,18]$. Further investigations showed that left ventricular (LV) contractile function was improved (or at least its worsening was prevented) in treated animals compared to non-treated animals. However, extensive data indicate that most cells that were transplanted into the heart do not survive long-term. Cell retention and survival are consistently low when injected into the myocardium, and even lower with intracoronary infusion $[17,49,50]$. These data are also consistent with the results derived from clinical trials that have transferred different types of autologous cells (including skeletal myoblasts, hematopoietic stem cells and mesenchymal stem cells) into the human myocardium [4-6], which generally came to the conclusion that these cells do not form a significant amount of new myocardium over the long term. Several challenges need to be addressed to improve cell engraftment, retention and survival. As an example, a challenge relates to the orientation of transplanted cells in the heart architecture. The alignment of transplanted cells with the host myocardium would enhance the force generation. In addition, it is generally unclear if cell transplantation is associated with the development of an efficient blood flow to supply the transplanted cells.
Most of the pre-clinical experiments investigating PSCbased therapies were performed in small animal models, which might not be the most appropriate for clinical disease scenarios. The development of electromechanical junctions between transplanted cells and the surrounding host cardiomyocytes is required for synchronous contraction. However, it is likely that human ESC- or iPSCsderived cardiomyocytes have difficulties coupling to rodent host myocardium because human cells cannot keep up with a rodent's high heart rate. Although electromechanical coupling of human ESC-derived cardiomyocytes with host cells has been reported in guinea pigs [51], it has potentially been underestimated. Therefore, the use of large animal models for testing human-derived cardiac stem cell therapies is preferred. Large animal models do, however, have limitations, including the requirement of larger numbers of cells, the development of suitable immunosuppression protocols and higher costs. Different groups have reported the administration of PSC-derived therapies in pigs and monkeys [18,52,53]. ESC-derived cardiovascular progenitors (selected on the SSEA-1 cell surface marker) have been investigated in a Rhesus monkey model of myocardial infarction [18] created by a 90-minute coronary occlusion/reperfusion protocol; the selected cells were injected 2 weeks later in the infarcted area during open-chest surgery. These cells engrafted into the infarcted monkey hearts and differentiated into morphologically mature cardiomyocytes. In a recent study, Xiong and colleagues [53] reported the administration of iPSC-derived vascular cells in a swine model of myocardial infarction. The transplanted cells were engineered to express a fluorescent reporter (green fluorescent protein) and the engraftment rate was estimated to be about 7\% after 1 week and about $2 \%$ after 4 weeks. Altogether, these studies suggest that improving cell survival over the long term is critical before considering future clinical applications [54].

\section{Defining the optimal delivery route to the myocardium}

An alternative approach to direct cell injection is to create a tissue-engineered version of cardiac muscle from human ESCs and iPSCs. In recent publications [55-57], it has been shown that the ex vivo combination of ESCs/ iPSCs with polymeric scaffolds allows the generation of tissue-engineered muscle constructs. The engineered tissues show coherent contractions 5 to 10 days after casting. They display a dense network of longitudinally oriented, interconnected and cross-striated cardiomyocytes, suggesting that the three-dimensional tissue format improves the maturation of cardiomyocytes [55]. It has been suggested that a geometrically straight structure of the tissue and cyclic strain favor cardiomyocyte maturation [55]. In an early study, human bioengineered 
cardiac tissues were transplanted onto the epicardium of a healthy athymic rat heart, showing graft survival and connection to the host myocardium and coronary circulation [56]. In another study [58], a composite construct made of adipose tissue-derived stromal cells and ESC-derived cardiac progenitors was applied surgically in monkeys that underwent myocardial infarction. Two months later, the progenitors had differentiated into cardiomyocytes and there was robust engraftment of the donor tissue associated with increased angiogenesis [58]. These data suggest that in vivo engraftment of engineered cardiac tissues created from ESC- or iPSC-derived cardiomyocytes represents an interesting alternative strategy to direct cell injection therapy. In addition to further investigations in pre-clinical models, the use of GMP-level materials would, however, be required for future clinical applications.

\section{Analyzing the appropriate endpoints post- delivery}

Studies evaluating stem cell-based therapies in vivo have primarily focused on the changes in LV function and in cardiovascular outcomes. The study methology, sample size, type of cells and route of administration typically differ between these studies, but most have evaluated the changes in LV ejection fraction as a surrogate of the benefit of stem-cell based therapies. The primary assumption is that the transplanted cells will directly replace the failing tissue and contribute to cardiac contraction, and that the higher the number of cells being engrafted the more the ejection fraction will be increased. There is, however, a large controversy on the mechanisms by which stem cellbased therapies contribute to improving cardiac function [1]. In addition or in place of direct action on contraction, it is plausible that paracrine effects or changes in the myocardial response to injury have an important contribution. In a recent study investigating the functional consequences of human iPSC administration in a swine model of myocardial infarction [53], it was found that iPSC transplantation mobilizes endogenous progenitor cells in the heart, thus reducing LV remodeling. Even if the factors secreted or released from injected cells remain to be fully characterized, the 'paracrine concept' has become very popular among the scientific community.

As a consequence, one of the major objectives will now be to correlate cell engraftment with improvements in local and global cardiac function as well as improvements in morbidity and mortality. Several strategies has been proposed to track the fate of the transplanted cells, including genome editing for molecular imaging [59] and magnetic resonance imaging-based reporter gene technology [60]. Magnetic resonance imaging cell tracking is particularly appealing in cardiology as it would allow a simultaneous assessment of cell engraftment and cardiac function. This can be achieved through genomic engineering of the transplanted cells or labeling these cells with super-paramagnetic iron oxide particles. These labeled cells might, however, only be compatible with pre-clinical studies. In a recent study conducted in 110 patients with dilated cardiomyopathy, cell homing of administered CD34+ cells was investigated by labeling a fraction of the cells with 99mTc-hexamethylpropylenamine and performing singlephoton emission computed tomography imaging 2 and 18 hours after the intracoronary delivery [61]. The average cell retention rate was $5 \%$ at 18 hours after injection but correlated well with functional outcomes at 3 and 12 months, those patients with above-average cell retention demonstrating a significant increase in LV ejection fraction. This study clearly paves the way for the design of a new generation of clinical cell therapy trials [62]. In these studies numerous parameters would be recorded, including cell homing and localization, global cardiac function, hemodynamic parameters and also cardiac volumes and dimensions. The rise of multimodality imaging (including in small animals) provides opportunities to measure global cardiac function parameters (such as LV ejection fraction and LV volumes) and local changes in cardiac fibrosis, scar areas or perfusion markers. Furthermore, this array of parameters could be measured at early and late time points after transplantation to more comprehensively evaluate the full impact of PSC-based therapies.

Finally, it has been suggested that transplanted cells can rapidly diffuse from the heart to other organs (that is, lungs, liver, kidneys, spleen) [63]. Whether this phenomenon exists with PSC-derived cardiomyocytes remains to be determined. However, as for any experimental drug, appropriate biodistribution and toxicology studies will need to be performed in animal models before moving into clinical investigations.

\section{Conclusion}

PSCs represent an appealing cell type for developing cell replacement therapies. Different initiatives have been launched to promote their development toward clinical applications. However, ESC/iPSC technologies have several specific issues that remain to be overcome, including the development of GMP-level PSC lines, the development of efficient protocols to generate pure populations of cardiomyocytes, and the development of techniques to improve the retention and survival rate of transplanted cells. Once these are overcome, the first clinical trials will then be on the horizon.

Note: This article is part of a thematic series on Cardiovascular regeneration edited by Ronald Li. Other articles in the series can be found online at http://stemcellres.com/series/cardiovascular. 


\section{Abbreviations}

ESC: Embyronic stem cell; GMP: Good manufacturing practice; HLA: Human leukocyte antigen; iPSC: Induced pluripotent stem cell; LV: Left ventricular; MHC: Major histocompatibility complex; PSC: Pluripotent stem cell.

\section{Competing interests}

The authors declare that they have no competing interests.

\section{Published: 09 Jan 2014}

\section{References}

1. Garbern JC, Lee RT: Cardiac stem cell therapy and the promise of heart regeneration. Cell Stem Cell 2013, 12:689-698.

2. Porrello ER, Mahmoud Al, Simpson E, Hill JA, Richardson JA, Olson EN, Sadek HA: Transient regenerative potential of the neonatal mouse heart. Science 2011, 331:1078-1080

3. Bergmann O, Bhardwaj RD, Bernard S, Zdunek S, Barnabe-Heider F, Walsh S, Zupicich J, Alkass K, Buchholz BA, Druid H, Jovinge S, Frisen J: Evidence for cardiomyocyte renewal in humans. Science 2009, 324:98-102.

4. Taylor DA: Cellular cardiomyoplasty with autologous skeletal myoblasts for ischemic heart disease and heart failure. Curr Control Trials Cardiovasc Med 2001, 2:208-210.

5. Dunbar CE, Cottler-Fox M, O'Shaughnessy JA, Doren S, Carter C, Berenson R, Brown S, Moen RC, Greenblatt J, Stewart FM, Leitman SF, Wilson WH, Cowan K, Young NS, Nienhuis AW: Retrovirally marked CD34-enriched peripheral blood and bone marrow cells contribute to long-term engraftment after autologous transplantation. Blood 1995, 85:3048-3057.

6. Schuleri KH, Feigenbaum GS, Centola M, Weiss ES, Zimmet JM, Turney J, Kellner J, Zviman MM, Hatzistergos KE, Detrick B, Conte JV, McNiece I, Steenbergen C, Lardo AC, Hare JM: Autologous mesenchymal stem cells produce reverse remodelling in chronic ischaemic cardiomyopathy. Eur Heart J 2009, 30:2722-2732.

7. Schenke-Layland K, Rhodes KE, Angelis E, Butylkova Y, Heydarkhan-Hagvall S, Gekas C, Zhang R, Goldhaber Jl, Mikkola HK, Plath K, MacLellan WR: Reprogrammed mouse fibroblasts differentiate into cells of the cardiovascular and hematopoietic lineages. Stem Cells 2008, 26:1537-1546.

8. Narazaki G, Uosaki H, Teranishi M, Okita K, Kim B, Matsuoka S, Yamanaka S, Yamashita JK: Directed and systematic differentiation of cardiovascular cells from mouse induced pluripotent stem cells. Circulation 2008, 118:498-506.

9. Zhang J, Wilson GF, Soerens AG, Koonce CH, Yu J, Palecek SP, Thomson JA, Kamp TJ: Functional cardiomyocytes derived from human induced pluripotent stem cells. Circ Res 2009, 104:e30-e41.

10. Thomson JA, Itskovitz-Eldor J, Shapiro SS, Waknitz MA, Swiergiel JJ, Marshall VS, Jones JM: Embryonic stem cell lines derived from human blastocysts. Science 1998, 282:1145-1147.

11. Takahashi K, Tanabe K, Ohnuki M, Narita M, Ichisaka T, Tomoda K, Yamanaka S: Induction of pluripotent stem cells from adult human fibroblasts by defined factors. Cell 2007, 131:861-872.

12. Grskovic M, Javaherian A, Strulovici B, Daley GQ: Induced pluripotent stem cells - opportunities for disease modelling and drug discovery. Nat Rev Drug Discov 2011, 10:915-929.

13. Garber K: Inducing translation. Nat Biotechnol 2013, 31:483-486.

14. Schwartz SD, Hubschman JP, Heilwell G, Franco-Cardenas V, Pan CK, Ostrick RM, Mickunas E, Gay R, Klimanskaya I, Lanza R: Embryonic stem cell trials for macular degeneration: a preliminary report. Lancet 2012, 379:713-720.

15. European Medicines Agency: Reflection paper on stem cell-based medicinal products. 2011. http://www.ema.europa.eu/docs/en_GB/document_library/ Scientific_guideline/2011/02/WC500101692.pdf.

16. Unger C, Skottman H, Blomberg P, Dilber MS, Hovatta O: Good manufacturing practice and clinical-grade human embryonic stem cell lines. Hum Mol Genet 2008, 17:R48-R53.

17. Laflamme MA, Chen KY, Naumova AV, Muskheli V, Fugate JA, Dupras SK, Reinecke H, Xu C, Hassanipour M, Police S, O'Sullivan C, Collins L, Chen Y, Minami E, Gill EA, Ueno S, Yuan C, Gold J, Murry CE: Cardiomyocytes derived from human embryonic stem cells in pro-survival factors enhance function of infarcted rat hearts. Nat Biotechnol 2007, 25:1015-1024.

18. Blin G, Nury D, Stefanovic S, Neri T, Guillevic O, Brinon B, Bellamy V, RuckerMartin C, Barbry P, Bel A, Bruneval P, Cowan C, Pouly J, Mitalipov S, Gouadon E, Binder P, Hagege A, Desnos M, Renaud JF, Menasche P, Puceat M: A purified population of multipotent cardiovascular progenitors derived from primate pluripotent stem cells engrafts in postmyocardial infarcted nonhuman primates. J Clin Invest 2010, 120:1125-1139.

19. Nussbaum J, Minami E, Laflamme MA, Virag JA, Ware CB, Masino A, Muskheli V, Pabon L, Reinecke H, Murry CE: Transplantation of undifferentiated murine embryonic stem cells in the heart: teratoma formation and immune response. FASEB J 2007, 21:1345-1357.

20. Gore A, Li Z, Fung HL, Young JE, Agarwal S, Antosiewicz-Bourget J, Canto I, Giorgetti A, Israel MA, Kiskinis E, Lee JH, Loh YH, Manos PD, Montserrat N, Panopoulos AD, Ruiz S, Wilbert ML, Yu J, Kirkness EF, Izpisua Belmonte JC, Rossi DJ, Thomson JA, Eggan K, Daley GQ, Goldstein LS, Zhang K: Somatic coding mutations in human induced pluripotent stem cells. Nature 2011, 471:63-67.

21. Lister R, Pelizzola M, Kida YS, Hawkins RD, Nery JR, Hon G, Antosiewicz-Bourget J, O'Malley R, Castanon R, Klugman S, Downes M, Yu R, Stewart R, Ren B, Thomson $J A$, Evans RM, Ecker JR: Hotspots of aberrant epigenomic reprogramming in human induced pluripotent stem cells. Nature 2011, 471:68-73.

22. Kehat I, Khimovich L, Caspi O, Gepstein A, Shofti R, Arbel G, Huber I, Satin J, Itskovitz-Eldor J, Gepstein L: Electromechanical integration of cardiomyocytes derived from human embryonic stem cells. Nat Biotechnol 2004, 22:1282-1289.

23. Xu C, Police S, Rao N, Carpenter MK: Characterization and enrichment of cardiomyocytes derived from human embryonic stem cells. Circ Res 2002, 91:501-508.

24. Zhu WZ, Van Biber B, Laflamme MA: Methods for the derivation and use of cardiomyocytes from human pluripotent stem cells. Methods $\mathrm{Mol}$ Biol 2011, 767:419-431.

25. Ren Y, Lee MY, Schliffke S, Paavola J, Amos PJ, Ge X, Ye M, Zhu S, Senyei G, Lum L, Ehrlich BE, Qyang Y: Small molecule Wnt inhibitors enhance the efficiency of BMP-4-directed cardiac differentiation of human pluripotent stem cells. J Mol Cell Cardiol 2011, 51:280-287.

26. Lian X, Hsiao C, Wilson G, Zhu K, Hazeltine LB, Azarin SM, Raval KK, Zhang J, Kamp TJ, Palecek SP: Robust cardiomyocyte differentiation from human pluripotent stem cells via temporal modulation of canonical Wnt signaling. Proc Natl Acad Sci U S A 2012, 109:E1848-E1857.

27. Dubois NC, Craft AM, Sharma P, Elliott DA, Stanley EG, Elefanty AG, Gramolini A, Keller G: SIRPA is a specific cell-surface marker for isolating cardiomyocytes derived from human pluripotent stem cells. Nat Biotechnol 2011, 29:1011-1018.

28. Tohyama S, Hattori F, Sano M, Hishiki T, Nagahata Y, Matsuura T, Hashimoto H, Suzuki T, Yamashita H, Satoh Y, Egashira T, Seki T, Muraoka N, Yamakawa H, Ohgino Y, Tanaka T, Yoichi M, Yuasa S, Murata M, Suematsu M, Fukuda K: Distinct metabolic flow enables large-scale purification of mouse and human pluripotent stem cell-derived cardiomyocytes. Cell Stem Cell 2013, 12:127-137.

29. Hattori F, Chen H, Yamashita H, Tohyama S, Satoh YS, Yuasa S, Li W, Yamakawa H, Tanaka T, Onitsuka T, Shimoji K, Ohno Y, Egashira T, Kaneda R, Murata M, Hidaka K, Morisaki T, Sasaki E, Suzuki T, Sano M, Makino S, Oikawa S, Fukuda K: Nongenetic method for purifying stem cell-derived cardiomyocytes. Nat Methods 2010, 7:61-66.

30. Buta C, David R, Dressel R, Emgard M, Fuchs C, Gross U, Healy L, Hescheler J, Kolar R, Martin U, Mikkers H, Muller FJ, Schneider RK, Seiler AE, Spielmann H, Weitzer G: Reconsidering pluripotency tests: do we still need teratoma assays? Stem Cell Res 2013, 11:552-562.

31. Yang L, Soonpaa MH, Adler ED, Roepke TK, Kattman SJ, Kennedy M, Henckaerts E, Bonham K, Abbott GW, Linden RM, Field LJ, Keller GM: Human cardiovascular progenitor cells develop from a KDR + embryonicstem-cell-derived population. Nature 2008, 453:524-528.

32. Lundy SD, Zhu WZ, Regnier M, Laflamme MA: Structural and functional maturation of cardiomyocytes derived from human pluripotent stem cells. Stem Cells Dev 2013, 22:1991-2002

33. Kim C, Wong J, Wen J, Wang S, Wang C, Spiering S, Kan NG, Forcales S, Puri PL, Leone TC, Marine JE, Calkins H, Kelly DP, Judge DP, Chen HS: Studying arrhythmogenic right ventricular dysplasia with patient-specific iPSCs. Nature 2013, 494:105-110.

34. van Laake LW, Passier R, Monshouwer-Kloots J, Verkleij AJ, Lips DJ, Freund C, den Ouden K, Ward-van Oostwaard D, Korving J, Tertoolen LG, van Echteld CJ, Doevendans PA, Mummery CL: Human embryonic stem cell-derived cardiomyocytes survive and mature in the mouse heart and transiently improve function after myocardial infarction. Stem Cell Res 2007, 1:9-24.

35. de Almeida PE, Ransohoff JD, Nahid A, Wu JC: Immunogenicity of pluripotent stem cells and their derivatives. Circ Res 2013, 112:549-561.

36. Draper JS, Pigott C, Thomson JA, Andrews PW: Surface antigens of human embryonic stem cells: changes upon differentiation in culture. $J$ Anat 2002, 200:249-258. 
37. Drukker M: Recent advancements towards the derivation of immunecompatible patient-specific human embryonic stem cell lines. Semin Immunol 2008, 20:123-129.

38. Drukker M, Katz G, Urbach A, Schuldiner M, Markel G, Itskovitz-Eldor J, Reubinoff B, Mandelboim O, Benvenisty N: Characterization of the expression of MHC proteins in human embryonic stem cells. Proc Natl Acad Sci U S A 2002, 99:9864-9869.

39. Drukker $M$, Benvenisty $N$ : The immunogenicity of human embryonic stem-derived cells. Trends Biotechnol 2004, 22:136-141.

40. Kim K, Lerou P, Yabuuchi A, Lengerke C, Ng K, West J, Kirby A, Daly MJ, Daley GQ: Histocompatible embryonic stem cells by parthenogenesis. Science 2007, 315:482-486.

41. Revazova ES, Turovets NA, Kochetkova OD, Agapova LS, Sebastian JL, Pryzhkova MV, Smolnikova VI, Kuzmichev LN, Janus JD: HLA homozygous stem cell lines derived from human parthenogenetic blastocysts. Cloning Stem Cells 2008, 10:11-24.

42. Zhao $T$, Zhang $Z N$, Rong $Z, X u$ Y: Immunogenicity of induced pluripotent stem cells. Nature 2011, 474:212-215.

43. Stadtfeld M, Apostolou E, Akutsu H, Fukuda A, Follett P, Natesan S, Kono T, Shioda T, Hochedlinger K: Aberrant silencing of imprinted genes on chromosome $12 \mathrm{qF} 1$ in mouse induced pluripotent stem cells. Nature 2010, 465:175-181.

44. Guha P, Morgan JW, Mostoslavsky G, Rodrigues NP, Boyd AS: Lack of immune response to differentiated cells derived from syngeneic induced pluripotent stem cells. Cell Stem Cell 2013, 12:407-412.

45. Araki R, Uda M, Hoki Y, Sunayama M, Nakamura M, Ando S, Sugiura M, Ideno H, Shimada A, Nifuji A, Abe M: Negligible immunogenicity of terminally differentiated cells derived from induced pluripotent or embryonic stem cells. Nature 2013, 494:100-104.

46. Nakajima F, Tokunaga K, Nakatsuji N: Human leukocyte antigen matching estimations in a hypothetical bank of human embryonic stem cell lines in the Japanese population for use in cell transplantation therapy. Stem Cells 2007, 25:983-985.

47. Zimmermann A, Preynat-Seauve O, Tiercy JM, Krause KH, Villard J: Haplotypebased banking of human pluripotent stem cells for transplantation: potential and limitations. Stem Cells Dev 2012, 21:2364-2373.

48. Laflamme MA, Gold J, Xu C, Hassanipour M, Rosler E, Police S, Muskheli V, Murry CE: Formation of human myocardium in the rat heart from human embryonic stem cells. Am J Pathol 2005, 167:663-671.

49. Qiao H, Surti S, Choi SR, Raju K, Zhang H, Ponde DE, Kung HF, Karp J, Zhou $R$ : Death and proliferation time course of stem cells transplanted in the myocardium. Mol Imaging Biol 2009, 11:408-414.

50. Zhang M, Methot D, Poppa V, Fujio Y, Walsh K, Murry CE: Cardiomyocyte grafting for cardiac repair: graft cell death and anti-death strategies. $J$ Mol Cell Cardiol 2001, 33:907-921.

51. Shiba Y, Fernandes S, Zhu WZ, Filice D, Muskheli V, Kim J, Palpant NJ, Gantz J, Moyes KW, Reinecke H, Van Biber B, Dardas T, Mignone JL, Izawa A, Hanna R, Viswanathan M, Gold JD, Kotlikoff MI, Sarvazyan N, Kay MW, Murry CE, Laflamme MA: Human ES-cell-derived cardiomyocytes electrically couple and suppress arrhythmias in injured hearts. Nature 2012, 489:322-325.

52. Li X, Zhang F, Song G, Gu W, Chen M, Yang B, Li D, Wang D, Cao K: Intramyocardial injection of pig pluripotent stem cells improves left ventricular function and perfusion: a study in a porcine model of acute myocardial infarction. PLOS One 2013, 8:e66688.

53. Xiong Q, Ye L, Zhang P, Lepley M, Tian J, Li J, Zhang L, Swingen C, Vaughan JT, Kaufman DS, Zhang J: Functional consequences of human induced pluripotent stem cell therapy: myocardial ATP turnover rate in the in vivo swine heart with postinfarction remodeling. Circulation 2013, 127:997-1008

54. Terrovitis JV, Smith RR, Marban E: Assessment and optimization of cell engraftment after transplantation into the heart. Circ Res 2010, 106:479-494.

55. Schaaf S, Shibamiya A, Mewe M, Eder A, Stohr A, Hirt MN, Rau T, Zimmermann WH, Conradi L, Eschenhagen T, Hansen A: Human engineered heart tissue as a versatile tool in basic research and preclinical toxicology. PLoS One 2011, 6:e26397.

56. Tulloch NL, Muskheli V, Razumova MV, Korte FS, Regnier M, Hauch KD, Pabon L, Reinecke H, Murry CE: Growth of engineered human myocardium with mechanical loading and vascular coculture. Circ Res 2011, 109:47-59

57. Didie M, Christalla P, Rubart M, Muppala V, Doker S, Unsold B, El-Armouche A, Rau T, Eschenhagen T, Schwoerer AP, Ehmke H, Schumacher U, Fuchs S,
Lange C, Becker A, Tao W, Scherschel JA, Soonpaa MH, Yang T, Lin Q, Zenke M, Han DW, Scholer HR, Rudolph C, Steinemann D, Schlegelberger B, Kattman S, Witty A, Keller G, Field $\sqcup$, et al: Parthenogenetic stem cells for tissue-engineered heart repair. J Clin Invest 2013, 123:1285-1298.

58. Bel A, Planat-Bernard V, Saito A, Bonnevie L, Bellamy V, Sabbah L, Bellabas L, Brinon B, Vanneaux V, Pradeau P, Peyrard S, Larghero J, Pouly J, Binder P, Garcia S, Shimizu T, Sawa Y, Okano T, Bruneval P, Desnos M, Hagege AA, Casteilla L, Puceat M, Menasche P: Composite cell sheets: a further step toward safe and effective myocardial regeneration by cardiac progenitors derived from embryonic stem cells. Circulation 2010, 122:S118-S123.

59. Wang Y, Zhang WY, Hu S, Lan F, Lee AS, Huber B, Lisowski L, Liang P, Huang M, de Almeida PE, Won JH, Sun N, Robbins RC, Kay MA, Urnov FD, Wu JC: Genome editing of human embryonic stem cells and induced pluripotent stem cells with zinc finger nucleases for cellular imaging. Circ Res 2012, 111:1494-1503.

60. Campan M, Lionetti V, Aquaro GD, Forini F, Matteucci M, Vannucci L, Chiuppesi F, Di Cristofano C, Faggioni M, Maioli M, Barile L, Messina E, Lombardi M, Pucci A, Pistello M, Recchia FA: Ferritin as a reporter gene for in vivo tracking of stem cells by $1.5-\mathrm{T}$ cardiac MRI in a rat model of myocardial infarction. Am J Physiol Heart Circ Physiol 2011, 300:H2238-H2250.

61. Vrtovec B, Poglajen G, Lezaic L, Sever M, Domanovic D, Cernelc P, Socan A, Schrepfer S, Torre-Amione G, Haddad F, Wu JC: Effects of intracoronary CD34+ stem cell transplantation in nonischemic dilated cardiomyopathy patients: 5-year follow-up. Circ Res 2013, 112:165-173.

62. Assmus B, Zeiher AM: Early cardiac retention of administered stem cells determines clinical efficacy of cell therapy in patients with dilated cardiomyopathy. Circ Res 2013, 112:6-8.

63. Dow J, Simkhovich BZ, Kedes L, Kloner RA: Washout of transplanted cells from the heart: a potential new hurdle for cell transplantation therapy. Cardiovasc Res 2005, 67:301-307.

\subsection{6/scrt390}

Cite this article as: Hulot et al:: Considerations for pre-clinical models and clinical trials of pluripotent stem cell-derived cardiomyocytes. Stem Cell Research \& Therapy 2014, 5:1 